\title{
Coxsackie Group B Virus Infection and Acute Diarrhoea Occurring among Children in Costa Rica*
}

\author{
WILLIAM PELON, VICTOR M. VILLAREJOS, JOHNG S. RHIM $†$, and FRED J. PAYNE \\ From Louisiana State University-International Center for Medical Research and Training, in collaboration with \\ the Ministry of Health of Costa Rica and the University of Costa Rica
}

Although no evidence has been reported linking infection by members of the Coxsackie Group B viruses with the aetiology of endemic diarrhoea, the results of several virological investigations into sporadic outbreaks of this disease have suggested a causal relation between infection by the Coxsackie Group B viruses and the accompanying diarrhoea syndrome (Heggie, Schultz, Gutekunst, Rosenbaum, and Miller, 1960; Felici, Archetti, Russi, Bellocchi, and Marzi, 1961; Guardiola, Figueroa de Gonzalez, Kauder, Muñoz, Lopez, Gadea, and Funkenbusch, 1964; Zakstelskaya, Tyan-Mao, and Feklisova, 1964).

Further evidence supporting the above findings is obtained from an accumulation of clinical data from cases found infected with various Coxsackie B virus types and in which diarrhoea was among the symptoms described (Johnsson, 1954; Ginevri and Felici, 1959; Felici and Gregorig, 1959; Artenstein, Cadigan, and Buescher, 1964; Cramblett, Moffet, Black, Shulenberger, Smith, and Colonna, 1964; Sanyal, Mahdavy, Gabrielson, Vidone, and Browne, 1965).

Presented here are the virological findings and their relation to acute diarrhoea, i.e. with onset of diarrhoea within 24 hours in relation to the time of specimen collection, uncovered in the course of a series of random horizontal surveys conducted in Costa Rica in 12 widely separated communities during an 8-month period from February to September 1963 (Fig. 1).

Diarrhoea was defined as 3 or more loose stools within a 24-hour period, except in the case of infants less than 1 year of age for whom 6 or more loose stools were required.

Received April 4, 1966.

* This investigation was supported by Public Health Service Research Grant TW00148 from the Office of International Research of the National Institutes of Health.

t At the Laboratory of Tropical Virology, National Institute of Allergy and Infectious Diseases, National Institutes of Health, Bethesda 14, Maryland, U.S.A.

\section{Material and Methods}

Epidemiology. Twelve communities of approximately the same size, i.e. 3000 inhabitants, representative of the different geographic, climatic, ethnic, and socio-economic zones of the country, were studied in horizontal surveys throughout Costa Rica.

Since in a series of pilot surveys diarrhoeal diseases and intestinal infections were found to be most prevalent among children, the population sample was randomly selected from those families which had children under 10 years of age. The method of selection used gave each child in this age-group in the community an equal opportunity to be included in the sample.

Virological and clinical examinations were performed only on this sub-sample of 1811 children under 10 years of age, which comprised the study population.

Specimens for virological examination were submitted by 1584 people $(87 \cdot 5 \%)$. A portion of the stool specimen was transferred to a sterile container and kept refrigerated for transport to the virology laboratory on the day of collection. If the locality was remote, the specimens were kept under refrigeration overnight and were sent to the laboratory the next morning by air.

Virology. $20 \%$ extracts of collected faeces, prepared in a serum-free medium consisting of $0.5 \%$ lactalbumin hydrolysate in Hanks' balanced salt solution and containing 1000 units of penicillin and $100 \mu \mathrm{g}$. each of streptomycin and polymyxin B per ml., were inoculated into cultures of HEp-2 cells, into primary cultures of Rhesus monkey renal (MK) cells, and into newborn (less than 18 hours old) Swiss albino mice (Webster strain), the latter by the technique of Hale and co-workers described elsewhere (Hale, Doraisingham, Kanagaratnam, Leong, and Monteiro, 1959). Suspected agents isolated in the cell cultures were passaged into $\mathrm{HEp}-2$ and $\mathrm{MK}$ cells for confirmation and characterization. $20 \%$ extracts were prepared from mice found paralysed, moribund, or dead after the first $\mathbf{2 4}$ hours following inoculation and were inoculated into newborn mice to confirm virus isolation.

Agents isolated from faecal extracts were identified using the usual tube neutralization procedure versus 100 antibody units of specific rabbit antisera for Coxsackie Group A, Type 9, and the Coxsackie Group B, Polio and ECHO virus types. ${ }^{\star}$ Isolates were considered as

* Biological Reagents Section, Communicable Disease Center, Atlanta, Georgia, U.S.A. 


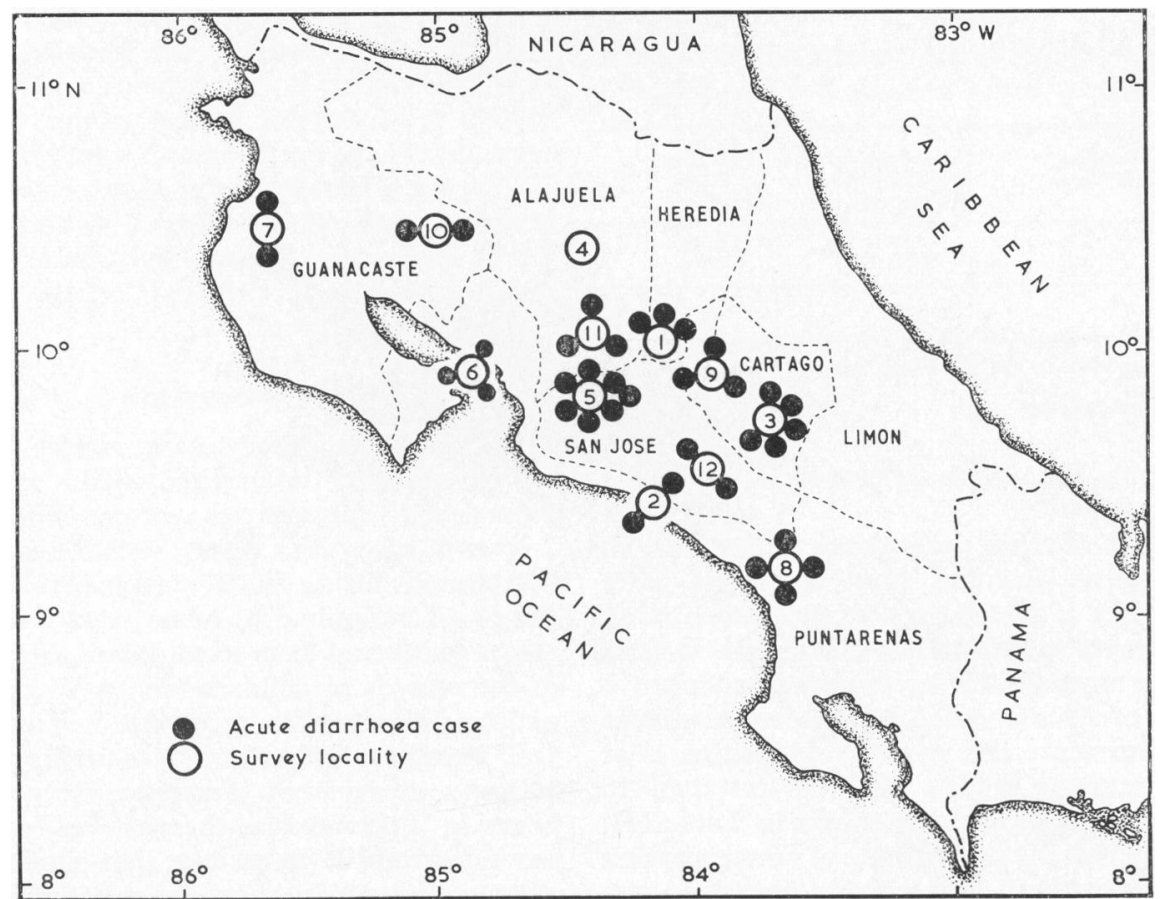

Fig. 1.-Location of cases of acute diarrhoea (less than 24 hours from onset) in Costa Rica.

Coxsackie Group A types on the basis of criteria previously considered acceptable (Ramos-Alvarez and Sabin, 1958).

\section{Results}

Preliminary analyses of virus isolation data employing a tentative system of classification based upon host susceptibility, passage characteristics, and distinctive cytopathology suggested an association between the diarrhoeas encountered in the surveys of the various communities and infections by agents considered as Coxsackie Group B types (Table I). When isolations of such agents from acute diarrhoea (i.e. 24 hours or less between onset and the time of specimen collection) were compared with those from children experiencing no diarrhoea, the differences appeared even more marked. An examination of the data on the basis of diarrhoea rates occurring among infants infected and non-infected with agents considered as Coxsackie $B$ types revealed that the frequency of diarrhoea among the infected infants was almost twice that observed among the non-

\section{TABLE I}

Isolation Rates of Tentatively Classified Enteric Viruses and Point Prevalence of Diarrhoea Among Costa Rican Children Less Than 10 Years of Age

\begin{tabular}{|c|c|c|c|c|c|c|c|c|}
\hline \multirow{2}{*}{\multicolumn{3}{|c|}{ Children $<10$ Years of Age }} & \multirow{2}{*}{$\begin{array}{l}\text { No } \\
\text { Examined }\end{array}$} & \multicolumn{5}{|c|}{$\begin{array}{c}\text { Percentage of Isolates Tentatively Classified }{ }^{\star} \text { as Members of } \\
\text { Indicated Virus Groups }\end{array}$} \\
\hline & & & & Adeno & Polio & ECHO & Cox. A & Cox. B \\
\hline $\begin{array}{l}\text { With acute diarrhoea } \\
\text { With diarrhoea } \neq \\
\text { Without diarrhoea } \\
\text { With diarrhoea data lacking }\end{array}$ & $\begin{array}{l}\cdots \\
\cdots \\
\cdots\end{array}$ & $\begin{array}{l}\cdots \\
\cdots \\
\cdots\end{array}$ & $\begin{array}{r}36 \\
118 \\
1421 \\
9\end{array}$ & $\begin{array}{r}2 \cdot 8 \\
4 \cdot 2 \\
5 \cdot 6 \\
11 \cdot 1\end{array}$ & $\begin{array}{r}-\overline{3 \cdot 4} \\
1 \cdot 3 \\
11 \cdot 1\end{array}$ & $\begin{array}{c}19 \cdot 4 \\
26 \cdot 3 \\
27 \cdot 0 \\
-\end{array}$ & $\begin{array}{l}19 \cdot 4 \\
15 \cdot 3 \\
14 \cdot 7 \\
22 \cdot 2\end{array}$ & $\begin{array}{l}41 \cdot 7 \\
21 \cdot 2 \\
12 \cdot 2 \\
11 \cdot 1\end{array}$ \\
\hline Total $\quad \ldots$ & . & $\ldots$ & 1584 & $5 \cdot 4$ & $1 \cdot 5$ & $26 \cdot 5$ & $14 \cdot 9$ & $13 \cdot 6$ \\
\hline
\end{tabular}

* Based upon host spectrum, passage characteristics, and distinctive cytopathology.

+24 hours or less between onset and time of specimen collection.

$\$$ More than 24 hours between onset and time of specimen collection. 
TABLE II

Point Prevalence of Diarrhoea among Infants Infected and Non-infected with Coxsackie B Virus Types*

\begin{tabular}{|c|c|c|c|}
\hline \multicolumn{2}{|c|}{$\begin{array}{c}\text { Status with Respect } \\
\text { to Coxsackie B Virus } \\
\text { Types }\end{array}$} & $\begin{array}{l}\text { No. of Infants } \\
\text { in Indicated } \\
\text { Categoriest }\end{array}$ & $\begin{array}{c}\text { Diarrhoea } \\
\text { Rate } \\
(\%)\end{array}$ \\
\hline $\begin{array}{l}\text { Infected } \\
\text { Non-infected }\end{array}$ & $\begin{array}{l}\ldots \\
\cdots\end{array}$ & $\begin{array}{r}75 \\
206\end{array}$ & $\begin{array}{l}33 \cdot 2 \\
18 \cdot 4\end{array}$ \\
\hline Total examined & $\ldots$ & 281 & $22 \cdot 4$ \\
\hline
\end{tabular}

* Tentatively classified on the following basis; $\mathrm{MK}+, \mathrm{HEp}-2+$, newborn mouse + .

+3 to $<24$ months of age.

infected (Table II). This difference is statistically significant, $\mathrm{p}<0.01$.

On the basis of these preliminary indications, an analysis of virus isolations from acute and more prolonged cases of diarrhoea was undertaken, with the crude tentative classification of the isolates confirmed or amended by serological procedures.

The rates of virus isolation from faecal specimens collected from acute and more prolonged cases of diarrhoea occurring among children less than 10 years of age in Costa Rica are shown in Table III. It can be seen that the over-all rate of virus excretion as detected with the 3 host systems employed was quite high, averaging approximately $75 \%$ for the 3 categories investigated. The maximum rate of $83 \%$ was noted from faecal specimens of children whose onset of diarrhoea was 24 hours or less before the collection of specimen material. The distribution of the identified Coxsackie B types from these cases among the different communities under study is shown in Fig. 2.

If the over-all infection rates by the Coxsackie Group B types are examined, the maximum isolation rate $(47 \%)$ for these agents was also obtained from children with acute diarrhoeas, with types 4 and 5 predominating. This rate rapidly declined to an average frequency of $9 \%$ when diarrhoeas of 48 and
72-96 hours' duration before specimen collection were considered. In contrast, the isolation of the nonCoxsackie Group B virus types, i.e. members of the ECHO and Coxsackie A virus groups, from cases of acute diarrhoeas occurred at a somewhat lower rate $(25 \%)$, but gradually increased to an average of $45 \%$ from diarrhoeas of 48- and 72-96 hours' duration. These frequencies of virus isolation are graphically presented in Fig. 3. $14(15 \%)$ of the isolates have not yet been identified.

\section{Discussion}

In Costa Rica, diarrhoeas in infants and children are of common occurrence, with an anticipated average of 10 episodes per year per child of less than 2 years of age. As a result, such illnesses are often not treated during the acute phases. Therapy, if employed, is limited to home remedies or medicaments purchased from local pharmacies. A review of the records of children who have attended outpatient clinics or who have been hospitalized in San José because of diarrhoea has indicated that the majority experienced diarrhoea for periods of 48 hours or longer before therapy was sought. It is not unreasonable to assume that similar situations exist elsewhere in areas where diarrhoeas are a common problem.

It should be emphasized that the 36 acute cases of diarrhoea shown in Fig. 1 were not deliberately selected for study, but were uncovered by chance during a random series of horizontal surveys conducted in 12 Costa Rican communities. Although acute diarrhoeas, as defined, were observed in 11 of the 12 survey localities, subjects actually experiencing an episode of diarrhoea during the time of interview were encountered in all the villages under investigation.

The data presented in Table III suggest a possible aetiological relation between infection by the Coxsackie Group B virus types and a proportion

TABLE III

Rates of Isolation of Coxsackie B and Non-Coxsackie B Virus Types from Acute and Prolonged Episodes of Diarrhoea

\begin{tabular}{|c|c|c|c|c|c|c|c|c|c|c|}
\hline \multirow{2}{*}{$\begin{array}{c}\text { Time Between } \\
\text { Onset of } \\
\text { Diarrhoea } \\
\text { and Specimen } \\
\text { Collection }\end{array}$} & \multirow{2}{*}{$\begin{array}{c}\text { No. of } \\
\text { Children } \\
\text { with } \\
\text { Diarrhoea } \\
\text { Tested }\end{array}$} & \multirow{2}{*}{$\begin{array}{c}\text { No. Found } \\
\text { Excreting } \\
\text { Virus }\end{array}$} & \multicolumn{5}{|c|}{$\begin{array}{l}\text { No. of Isolates Identified as } \\
\text { Coxsackie B Types }\end{array}$} & \multirow{2}{*}{$\begin{array}{c}\text { Total } \\
\text { No. of } \\
\text { Coxsackie } \\
\text { B Types } \\
\text { Isolated }\end{array}$} & \multirow{2}{*}{$\begin{array}{l}\text { No. of Non- } \\
\text { Coxsackie } \\
\text { B Types }\end{array}$} & \multirow{2}{*}{$\begin{array}{l}\text { No. } \\
\text { Not } \\
\text { Identi- } \\
\text { fied }\end{array}$} \\
\hline & & & 1 & 2 & 3 & 4 & 5 & & & \\
\hline $\begin{array}{l}24 \text { hours or less } \\
48 \text { hours } . \\
72-96 \text { hours }\end{array}$ & $\begin{array}{l}36 \\
29 \\
29\end{array}$ & $\begin{array}{l}30(83 \%) \\
19(65 \cdot 5 \%) \\
22(76 \%)\end{array}$ & $\frac{1}{1}$ & $\frac{1}{1}$ & $\frac{1}{1}$ & - & $\begin{array}{l}4 \\
1 \\
1\end{array}$ & $\begin{array}{c}17(47 \%) \\
1(3 \%) \\
4(14 \%)\end{array}$ & $\begin{array}{r}9(25 \%) \\
14(48 \%) \\
12(41 \%)\end{array}$ & $\begin{array}{l}4^{\star} \\
4^{\star} \\
6 \dagger\end{array}$ \\
\hline Total & 94 & $71(75 \cdot 5 \%)$ & 2 & 2 & 2 & 10 & 6 & $22(23 \%)$ & $35(37 \%)$ & 14 \\
\hline
\end{tabular}

* All tissue culture + , newborn mouse $+. \quad+2$ tissue culture,+ mouse,+ 4 tissue culture + only. 


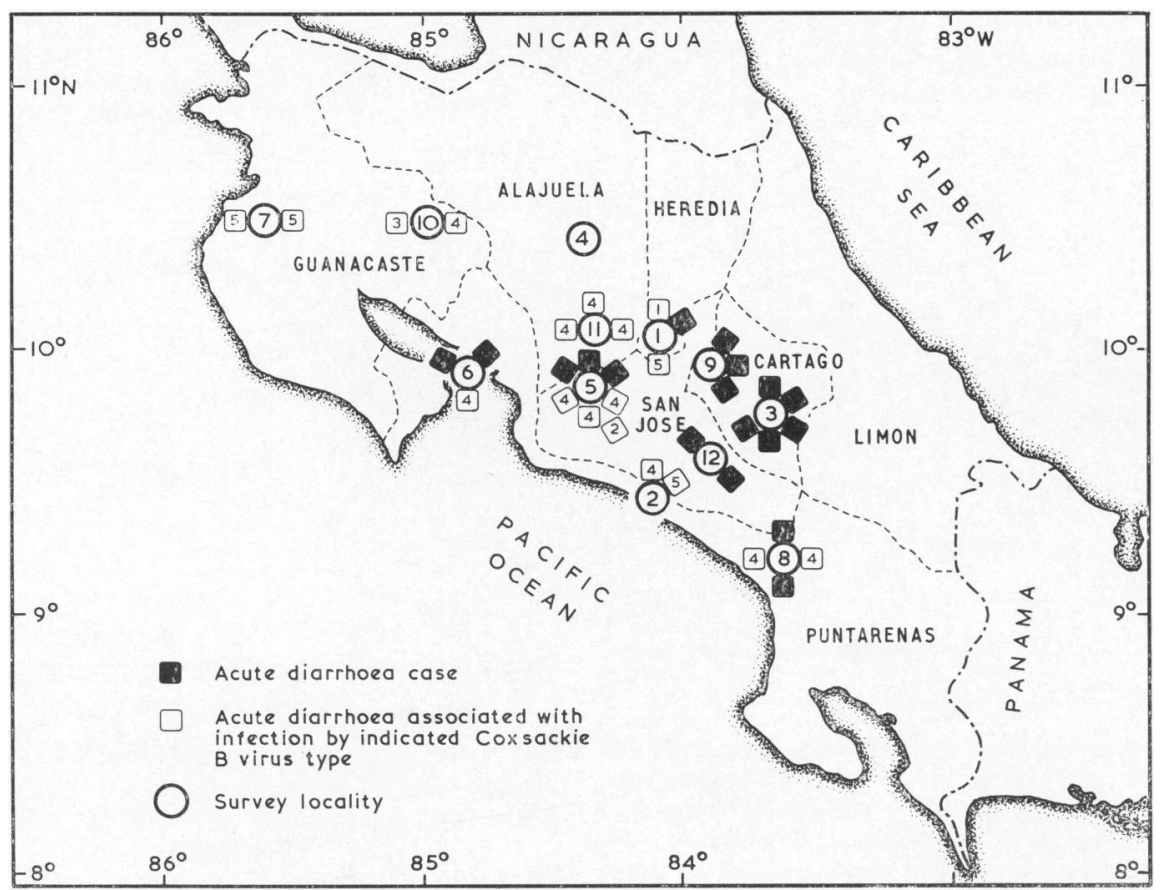

Fig. 2.-Distribution of specific Coxsackie Group B virus types found associated with cases of acute diarrhoea in Costa Rica, 1963.

of the endemic diarrhoeas occurring among the younger children in Costa Rica. It is of interest to note that the isolations of the Coxsackie $B$ virus types from cases of acute diarrhoea were not limited to a particular community, which would be suggestive of a localized outbreak similar to that observed elsewhere (Felici et al., 1961). As seen in Fig. 2, these were broadly distributed, being obtained from specimens collected from 8 of the 11 communities where this syndrome, as defined, was observed.

Although $15 \%$ of the isolates have not yet been identified, it is doubtful whether such information would alter the existing data significantly. This is illustrated in Fig. 4 and 5 . If it is assumed that the unidentified agents isolated in both cell cultures and newborn mice were members of the Coxsackie B group and those isolated in cell cultures only were non-Coxsackie Group B viruses (Fig. 4), some differences in the frequencies of isolation would be observed when compared with the data presented in Fig. 3. Although an increase in the isolation rates of the Coxsackie Group B viruses would occur (Fig. 4), the slopes of the curves for virus isolation from diarrhoeas of 24 and 48 hours' duration are identical when both figures are compared. Non-Coxsackie B agents (Fig. 4) also show an increase in the frequency of isolation from the 72-96 hour diarrhoeas. In contrast, if it is assumed that all of the unidentified

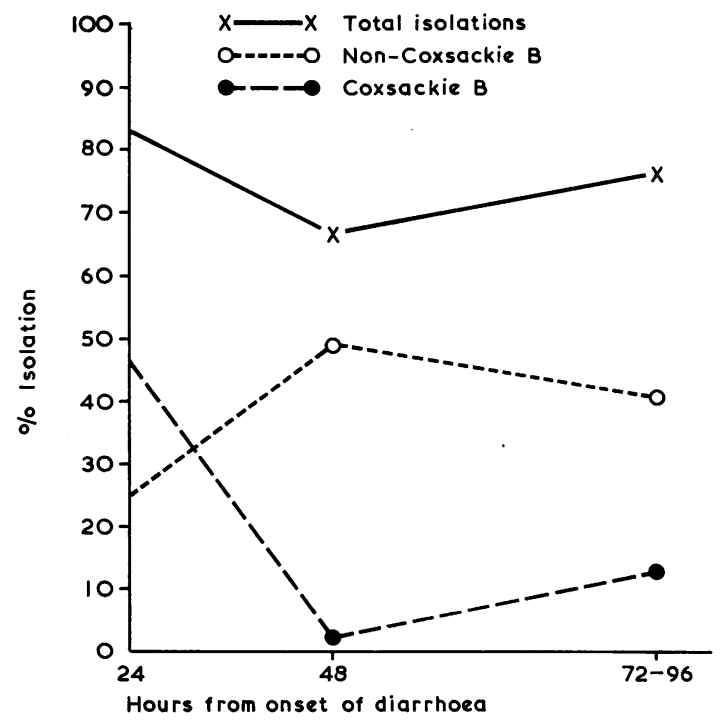

FIG. 3.-Virus isolation rates from acute and more prolonged cases of diarrhoea. 


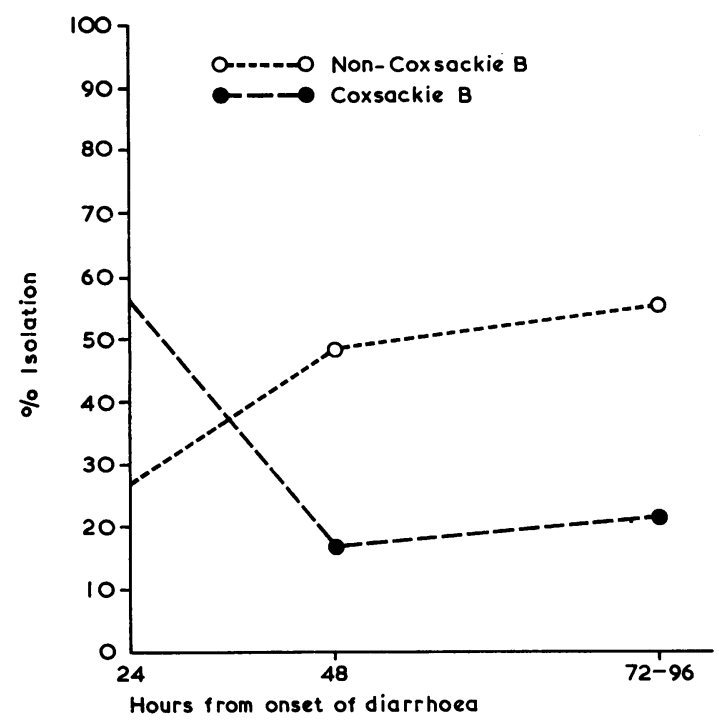

FIG. 4.-Hypothetical virus isolation rates from acute and more prolonged cases of diarrhoea, assuming that undentified isolates, positive in cell cultures and newborn mice were identified as Coxsackie $B$ types and those positive in cell cultures only were identified as non-Coxsackie $B$ types.

agents were ultimately identified as non-Coxsackie B types (Fig. 5), such findings would reduce differences in the rates of isolation of the Coxsackie $B$ and non-Coxsackie B types from diarrhoeas of 24 hours' duration, but would also tend to broaden the differences in the frequencies of isolation between the two groups from diarrhoeas of 48 and 72-96 hours' duration.

Although virological investigations of endemic diarrhoeas are not unique, the data presented thus far place strong emphasis upon the necessity of collecting specimen material from cases of diarrhoea during the acute phases of the disease, a procedure recognized and recommended for the recovery of most agents (Lennette, 1964).

Currently, it is not possible to project our findings in Costa Rica to other areas where endemic diarrhoeas prevail. Nevertheless, it is of interest to note that where virological investigations of diarrhoeas occurring in endemic areas have been carried out, the study population usually consisted of subjects who either were attending out-patient clinics or were hospitalized because of this disease (GuardiolaRotger et al., 1964; Reitano and Dardanoni, 1961; Young, Lindberg, Ortiz, Jahiel, Sochard, and Hemphill, 1962; Malherbe and Roux, 1963; Ramos-Alvarez and Olarte, 1964; Nuñez-Montiel, Herold, Castillo, Angelillo, Irazábal, Gómez Malaret, and Vitelli-Flores, 1965).

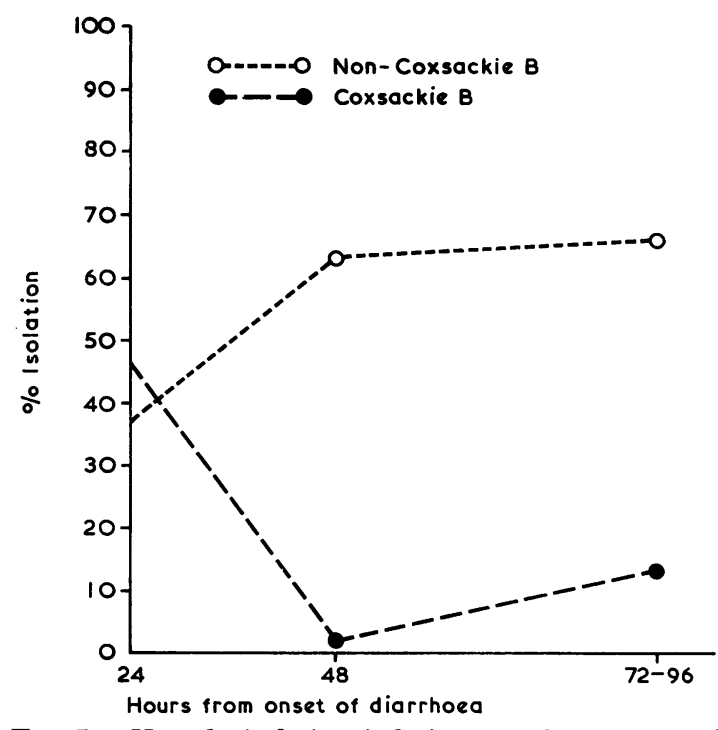

FIG. 5.- Hypothetical virus isolation rates from acute and more prolonged cases of diarrhoea, assuming that all unidentified isolates were identified as non-Coxsackie $B$ types.

In such studies, ratios of the non-Coxsackie Group B types as compared with the frequencies of isolation of Coxsackie Group B virus types from cases of diarrhoea (NCB : CB ratio) ranged from $2: 1$ to $62: 1$, with 5 of the 6 investigations reporting findings having ratios of $5: 1$ or greater. If the data from Costa Rica were analysed in a similar manner, the NCB : CB ratios ranged from $0.5: 1$ from acute diarrhoeas to $14: 1$ and $3: 1$ from diarrhoeas of 48 and 72-96 hours' duration, respectively.

Further support of the Costa Rican findings is obtained from one of the investigations described above (Guardiola-Rotger et al., 1964). Even though an over-all virus isolation rate of only $14 \%$ was obtained from cases of diarrhoea, $57 \%$ of the agents isolated were shown to be members of the Coxsackie B group, with 8 of the 9 Coxsackie B isolates classified as type 4 .

In view of the data obtained in Costa Rica, speculation now arises as to what the findings would have been in those investigations of endemic diarrhoeas mentioned above, if diarrhoeas during their acute phase (i.e. 24 hours or less between onset and the time that specimen material was collected) had been investigated.

\section{Summary}

Virological investigation of acute diarrhoeas (24 hours or less between onset and time of specimen) 


\section{Coxsackie Group B Virus Infection and Acute Diarrhoea}

and diarrhoeas of a more prolonged duration occurring among infants and children of Costa Rica have been carried out. Of the subjects studied, $\mathbf{7 5} \%$ were found to have been excreting virus. Coxsackie $B$ virus types were isolated at a rate of 47\% from acute diarrhoea specimens, with types 4 and 5 predominating. Non-Coxsackie $B$ virus types were isolated at a rate of $25 \%$ from similar specimen material. When specimens from diarrhoeas of 48 and 72-96 hours' duration were examined, the Coxsackie $B$ virus isolation rates declined to 3 and $14 \%$ respectively. In contrast, an increase in the non-Coxsackie $B$ virus types was observed, ranging from 41 to $48 \%$ in the diarrhoeas lasting 48 and 72-96 hours. The implications of these findings in relation to the possible viral aetiology of endemic diarrhoea in Costa Rica and elsewhere are discussed.

We gratefully acknowledge the untiring support of the personnel of the Ministry of Health of Costa Rica and the University of Costa Rica. From the Ministry of Health we particularly want to thank Dr. Max Terán Valls and Dr. Oscar Tristán, the Ministers of Health during the study, Dr. Rodrigo Jiménez Monge, Director of the Department of Epidemiology, and Dr. Arturo Romero, Director of the Department of Health Units. From the University of Costa Rica we should like to thank Dr. Mario Miranda Gutiérrez, Dean of the School of Medicine, Dr. Fernando Montero Gei, Dean of the School of Microbiology, and Dr. José Amador Guevara, Head of the Department of Preventive Medicine.

\section{REFERENCES}

Artenstein, M. S., Cadigan, F. C., Jr., and Buescher, E. L. (1964). Epidemic Coxsackie virus infection with mixed clinical manifestations. Ann. intern. Med., 60, 196.

Cramblett, H. G., Moffet, H. L., Black, J. P., Shulenberger, H., Smith, A., and Colonna, C. T. (1964). Coxsackie virus infections. F. Pediat., 64, 406.

Felici, A., Archetti, I., Russi, F., Bellocchi, C., and Marzi, F. (1961). Contribution to the study of diseases caused by the Coxsackie B group of viruses in Italy. III. Role of Coxsackie B virus, type 3 in summer diarrheal infections in infants and children. Arch. ges. Virusforsch., 11, 592.
- and Gregorig, B. (1959). Contribution to the study of diseases in Italy caused by the Coxsackie B group of viruses. II. Epidemiological, clinical, virological data obtained in the course of a summer outbreak caused by Coxsackie B-4 virus. ibid., 9, 317.

Ginevri, A., and Felici, A. (1959). Contribution to the study of diseases in Italy caused by Coxsackie B group of viruses. I. Clinical and virological aspects of an outbreak of Bornholm disease. ibid., $9,310$.

Guardiola-Rotger, A., Figueroa de Gonzalez, E., Kauder, E., Muñoz, A., Lopez, V. A., Gadea, D. E., and Funkenbusch, M. J. (1964). Studies on diarrheal diseases. F. Pediat., 65, 81.

Hale, J. H., Doraisingham, M., Kanagaratnam, K., Leong, K. W., and Monteiro, E. S. (1959). Large-scale use of Sabin type 2 attenuated poliovirus vaccine in Singapore during a type 1 poliomyelitis epidemic. Brit. med. $\mathcal{F} ., 1,1541$.

Heggie, A. D., Schultz, I., Gutekunst, R. R., Rosenbaum, M., and Miller, L. F. (1960). An outbreak of a summer febrile disease caused by Coxsackie B-2 virus. Amer. F. publ. Hlth, 50, 1342.

Johnsson, T. (1954). Family infections by Coxsackie viruses. Arch. ges. Virusforsch., 5, 384.

Lennette, E. H. (1964). General principles underlying laboratory diagnosis of viral and rickettsial infections. In Diagnostic Procedures for Viral and Rickettsial Diseases, ed. E. H. Lennette and N. J. Schmidt, 3rd ed., pp. 1-66. American Public Health Association, New York.

Malherbe, H., and Roux, P. (1963). The role of enteropathogenic bacteria and viruses in acute diarrhoeal disorders of infancy and childhood in Johannesburg. II. 'Non-specific' gastroenteritis. S. Afr. med. $\mathcal{F} ., 37,259$.

Nuñez-Montiel, O., Herold, F., Castillo, C., Angelillo, E., Irazábal, J., Gómez Malaret, S., and Vitelli-Flores, J. (1965). Investigación sobre enterovirus en Venezuela. II. Diarrea aguda febril. Acta cient. venez., 16, 65.

Ramos-Alvarez, M., and Olarte, J. (1964). Diarrheal diseases of children. Amer. F. Dis. Child., 107, 218.

-, and Sabin, A. B. (1958). Enteropathogenic viruses and bacteria: role in summer diarrheal diseases of infancy and early childhood. f. Amer. med. Ass., 167, 147.

Reitano, G., and Dardanoni, L. (1961). Enterobatteri ed enterovirus in casi di diarrea infantile in Sicilia. Riv. Ist. sieroter. ital., 36, 28.

Sanyal, S. K., Mahdavy, M., Gabrielson, M. O., Vidone, R. A., and Browne, M. J. (1965). Fatal myocarditis in an adolescent caused by Coxsackie virus, group B, type four. Pediatrics, 35, 36.

Young, V. M., Lindberg, R. B., Ortiz, A., Jahiel, D., Sochard, M. R., and Hemphill, J. J. (1962). Studies of infectious agents in infant diarrhea. III. Bacterial, viral and parasitic agents in feces of Puerto Rican children. Amer. F. trop. Med. Hyg., 11, 380.

Zakstelskaya, L. Y., Tyan-Mao, T., and Feklisova, L. V. (1964). On the etiology of diarrhea with respiratory syndrome in young children. (In Russian.) Vop. Virus., 9, 205. 